\title{
A POLICY FOR NUCLEAR-POWERED MARINE PROPULSION
}

\section{$\mathrm{D}$} ISCUSSING the technical situation in its report, Nuclear Power for Ship Propulsion*, the Padmoro Working Group on Marine Reactor Research points out that the U.S. Administration has already built an experimental merchant vessel, the Savannah (Nature, 184,677 , B.A. 15; 1959), which was roady for use in 1962 , and from Russia there have been many reports of the successful operation of the nuclear icebreaker Lenin. The Norwegians and Swedes have recently agreed on a joint programme on a boiling-water reactor. Besides the research on the Vulcain reactor, jointly with the Belgians, the U.K. Atomic Energy Authority carried out some research on the integral boiling reactor, but work on the design and development of the core structure revealed difficulties demanding a lengthy development programme. Because of this, research work was suspended when the dosign study was completod at tho end of 1963, pending consideration of the future programme. The theoretical and experimental core physies work on this design, however, confirmed that the "burnable poison' material incorporated in the fuel assembly to regulate the burn-up of the fuel shows considerable promise as an alternative technique to the "spectral shift' method of controlling nuclear reactivity used in the Vulcain design. As a result, in the lattor part of 1963 the Authority suggested an alternative core design known as the "burnable poison pressurized water reactor' and estimated that a prototype reactor might be ready in 1968 .

Further work is necessary before a clear judgment can be formed, and more research is required to establish the feasibility of the steam-cooled light water moderated reactor studies by the Mitchell Engineering Co., Peterborough, and the Fairfield Engineering Co., Glasgow. The Babcock and Wilcox Co. (United States) has a design concept, the consolidated nuclear steam generator, also incorporating the burnable poison technique in an integral design, of which a prototype could be ready in 1968, and an advanced design, the unified modular plant of the Combustion Engineering Co., of the same type could also be ready in four years time, while the U.S. General Electric Co. also has an air-cooled design of reactor, but for both the last-mentioned types a landbased prototype is bolieved to be desirable. The eventual capital and fuel costs of all these reactors are very difficult to estimate, but the Padmore Working Group concludes that, given the right arrangements, industry should be able to achieve a production cost of less than $£ 1$ million for a 20,000-shaft horse-power reactor installed in a ship, and, with adequate experience, designs bringing the costs within the range of $£ 500,000-£ 750,000$ should be possible. In the Group's judgment, no adequate justification exists at present for believing that any of these designs could be developed as better economic propositions in a marine application than the present integral pressurized-water reactor designs. Moreover, it regards its original recommendation in favour of these designs as justified. Nucloar marine power plants offer attractive possibilities of simplicity and reliability which should surpass that foreseeable for oil-fuollod machinery. These qualities are of great interest to ship-owners and very relevant to the ultimato prospects of nuclear propulsion at sea.

On the oconomic prospects, the Group observes that direct economic comparison is less favourable to nuclear

* Nuclear Ponver for Ship Propulsion: Report of the Working Group on Marine Reactor Research. Pp. 22. (Cmnd, 2358.) (London: H.M.S.O.,
1964.) 1s. Fid. net. See also p. 1247 of this issue of Nature. power than seemed probable a year ago, largely because of the reduction in the price of ships, the introduction of substantially larger diesel engines, and a marked reduction in the average price of bunker oil, while nuclcar fuel-cycle costs are now estimated to be about $0.05 d$. per shaft horse-power hour higher. On the other hand, it considers that, while conventional machinery will continue to improve, there is likely to be more scopo for develop. ment with nuclear reactors. No significant increase is foreseen in the scope for reducing fuel costs in ship operation, but nuclear power might offer possibilities in the reduction of the size of erews. The special operating characteristics of nuclear-fuelled ships are difficult to assess, but the reactor should eventually noed less running maintenance than oil-fired boilers or diesel engines.

As to the alternative courses possible, the Working Group sets out the following arguments in favour of constructing and testing a reactor now. An economic nuclear marine reactor for merchant ships will probably be doveloped some time in the future, without calling for an improbable degree of improvement on advancess already made by the Atomic Energy Authority. Britain is well placed for this purpose, partly as a result of the valuable design and research experience of the past two years in this field. Present-day designs of American merchant ships are no closer to being economic than Britain's, and if such a project is embarked on Britain will acquire the technology peculiar to reactors for merchant ships which we need at present. One of the problems encountered by the Savannah has concorned crews. Experience of these and of the practical problems of sea operation, as well as those of berthing and arranging port facilities, would derive from a ship-borno project and help to indicate the way to improve future designs. All this experience would put British engineering and shipbuilding firms into a strong position to retain orders from British ship-owners and to obtain thern from foreign shipping firms. Little further progress can be made in developing an economic type of reactor without actually constructing an experimental reactor or reactors.

Against starting a programme is tho absenco at present of any reactor type which holds firm promise of becoming economic. Nuclear reactors may prove to have no great future for propulsion of merchant ships even after further heavy oxpenditure on research and development. It is likely that any economic type of reactor developed could only be used in a limited number of large ships. operated intensively on a few long routes, with special terminal facilities. Moreover, the advantages of successful development of reactors, which are decisively the best and maintain a decisive lead, apart from prestige, may bo no more than marginal. It is also conceivable that the oventual economic reactor will be gas- or steam-cooled.

On the content of any such programme, the Working Group recommends the construction and testing of a reactor to the Vulcain design or the burnable poison pressurized water reactor of the U.K. Atomic Energy Authority. The balance of advantage lies with a shipborno project, and actual construction should be possible at the end of a year. In the phased programme outlined. sea-trials are contemplated in 1968. The Group is convinced that to continue with a marine research programme at the present level of about $£ 2$ million a year and not building a reactor until there is a better prospect of an economic design would be getting the worst of both worlds. Its alternative is to continue commitments under the joint Vulcain programme to 1967 and tidy up othor research during the present year. 